
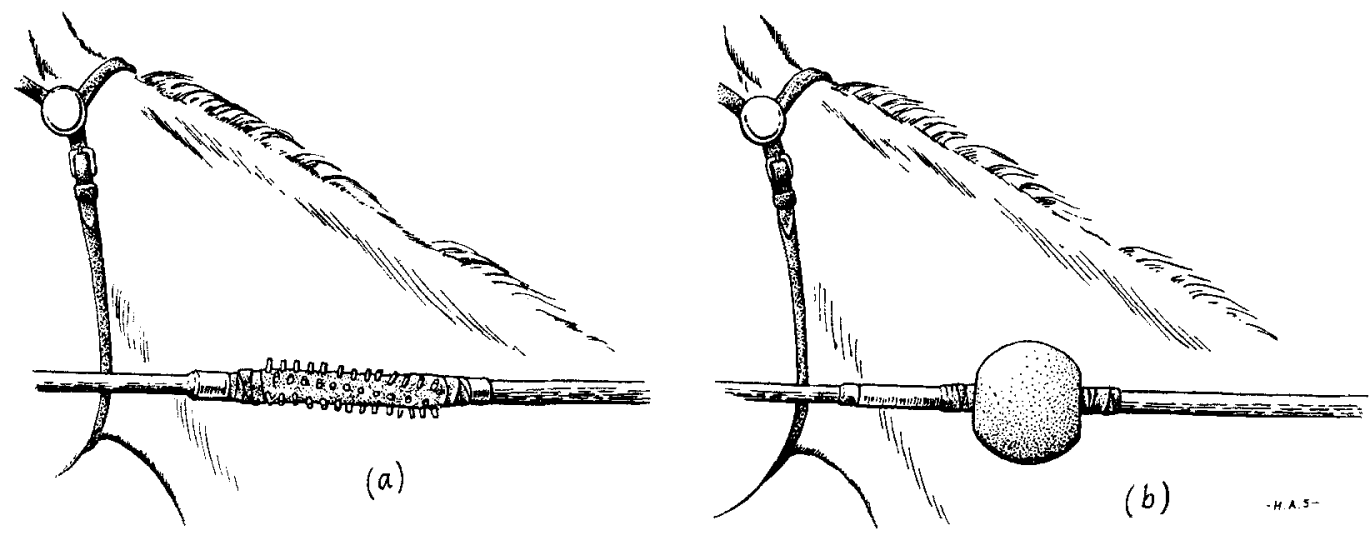

Fig. 2. 'Burrs' and 'balls' on head poles (drawn by H. A. Shelley, after अ. C. O'Brien in Harrison, 1968)

of the horses. Hence their purpose would have been to prevent the animal turning his head sharply towards his team mate; in other words, it had nothing to do with keeping him in the line of draught. The chief reason that would cause him to make this movement would be the natural intolerance of one stallion for another and their considerable disposition to bite; a bickering chariot team would hardly have been desirable. The difficulty encountered in this respect with earlier onager teams is well evidenced by the muzzles in which they were driven (Littauer, 1969, 296 with Fig. 6). Even Greek horses 800 years later still wore muzzles when led, even if these were removed in the bridling (Buschor, 1969 , pls. 132, 151 ).

Rieth has a note to the effect that Vienna fiacre drivers attached thick knobs to the outer traces of their horses on the level of their flanks to keep them from breaking from the line of draught (Rieth, r957, I53 n. I I). It is with his relatively freer hind quarters that the animal is able to swing out, but in ancient harnessing, in particular, the yoke would have kept the forehand quite rigidly in place.

The head poles are first depicted in Egypt in the Amarna period, and there is no evidence of them later than the Ramessides, although the latter circumstance may be due to paucity of figured documents. There is no evidence for them outside Egypt and, so far as we know, even Egyptian artists never illustrate them on foreign teams. MARY AIKEN LITTAUER

BORchardT, L. I9I. Ausgrabungen in Tell elAmarna 19I I, MDOG, XLVI, r3-27.

1912. Ausgrabungen in Tell el-Amarna $1911 / \mathrm{r} 2$, $M D O G$, XIVII $35^{-7}$.

BuschoR, E. r969. Griechische Vasen (Munich).

CARTER, H. 1927. The tomb of Tut-ankh-Amen (New York).

LitTauer, M. A. 1969. Bits and pieces, Antiquity, XLIII, 289-300.

O'BRIEN, J. C. I968. Bits, boots and bridles, in (ed.) J. C. Harrison, Care and training of the trotter and pacer (Columbus, Ohio), 419-526.

RIETH, A. I957. 'Halssporen' am Pferdegeschirr des Neuen Reiches, Mitt. des Instituts für Orientforschung, $v, 14^{8-54}$.

\title{
Aerial reconnaissance: recent results, 36
}

PLATE XXXVI

In archaeology the use of air photography as an instrument of discovery, as well as the value of photographs for showing a site in its present setting are the aspects most frequently emphasized. However, photographs taken under suitable conditions may also illustrate the natural surroundings, their present and their former condition, and may even be used to reconstruct past environments which, in Britain, were usually very different from those of today's man-made landscape, a creation largely of the last few hundred years. A field 


\section{ANTIQUITY}

archaeologist, whatever his particular study, must have some understanding of the background of contemporary geography and vegetation if he is to gather the fullest information. There are many instances where such knowledge has been indispensable for the understanding of settlement history or of distribution patterns.

Around the Wash, the Fenland, now divided between the counties of Lincolnshire, Huntingdonshire, Cambridgeshire and Norfolk provides an instance of striking geographical changes as yet understood only in part. The work of the Fenland Research Committee of some forty years ago did much to establish the character of the Fenland deposits, their conditions of deposition and chronological sequence, using not only archaeological methods but also the then comparatively novel techniques of pollen analysis. More recently, the agricultural settlement of the Fenland in the Roman period has been explored in a degree of detail accorded to few other rural districts in Roman Britain (Phillips, 1970). Study of air photographs combined with painstaking examination of sites on the ground has yielded an abundance of information about the settlement of the Fens in the Roman period, fundamental to all future studies.

The plates in the Geographical Society's Memoir have necessarily been chosen to show the character of individual sites, and are thus mainly views from a low altitude. Photographs of a rather different kind are necessary to illustrate the remarkable environmental changes that have taken place in the Fenland. To display an area of Fenland large enough to include an appreciable part of the present waterways and past river system, and to show its relationship to the Fenland edge, or to Fen 'islands', calls for photography at a considerably smaller scale than is customary for recording archaeological sites. Again, the extinct rivers are most readily visible, as Fowler demonstrated long ago (Fowler, r934), by reason of the contrast in tone between silt deposits forming low banks or 'roddons' that mark the former river courses and the black peat of the surrounding fens. By tracing these roddons, Fowler was able to plot many of these abandoned river courses. The silt composing the roddons accumulated in a marine or brackish water environment (it yields marine foraminifera), and slowly built up to a level slightly higher than the surrounding marshes (Godwin, I938) to form natural levees overlapping the peat of the Fens. The effect is most clearly seen in autumn or winter when the surface of most of the fields is bare soil, in which dampness may accentuate the contrast in tone, and shadows pick out the slight differences in relief. The natural variations in the soil also give rise in summer to crop patterns, and former water courses in the Fenland are frequently visible in this way, but owing to the agricultural rotation, only parts of the system are at any one time under crops that respond to these soil differences.

The vertical photograph (PL. xxxvi) of a part of the peat fens, $4.5 \times 5.3 \mathrm{~km}$. in extent, $E$ of Ramsey, in Huntingdonshire, was taken on 3 April 1969. The long sides of the photograph lie approximately $\mathrm{NE}$ and $\mathrm{SW}$. The whole area is intensively cultivated, and the fields were bare, or so nearly bare at the time of photography that the colours of the soil show clearly, giving a picture of the extinct river system of a part of the Fenland not easily matched in its completeness. FIG. I drawn from the photograph, will assist interpretation.

The built-up area of Ramsey, including the abbey and its precinct may be distinguished near the bottom left-hand corner. The town lies at the edge of the Fen basin where an 'island' of solid rock, here Oxford Clay, projects as a low ridge into the Fens as far as the Forty Foot Drain. Part of the outline of this 'island' is marked on FIG. I. Along the crest of the ridge, the ground nowhere quite reaches the lowest contour drawn on $1: 25,000$ OS maps, that at $25 \mathrm{ft}$. $\left(7^{\circ} 6 \mathrm{~m}\right.$.) above sea level. The whole of the rest of the photograph includes peat fen, which has attained its present state as a result of the drainage schemes of the seventeenth century, which made possible the laying out of the existing pattern of rectangular arable fields developed in the eighteenth and early nineteenth centuries (Darby, 1950). The chief interest of the photograph lies in the 


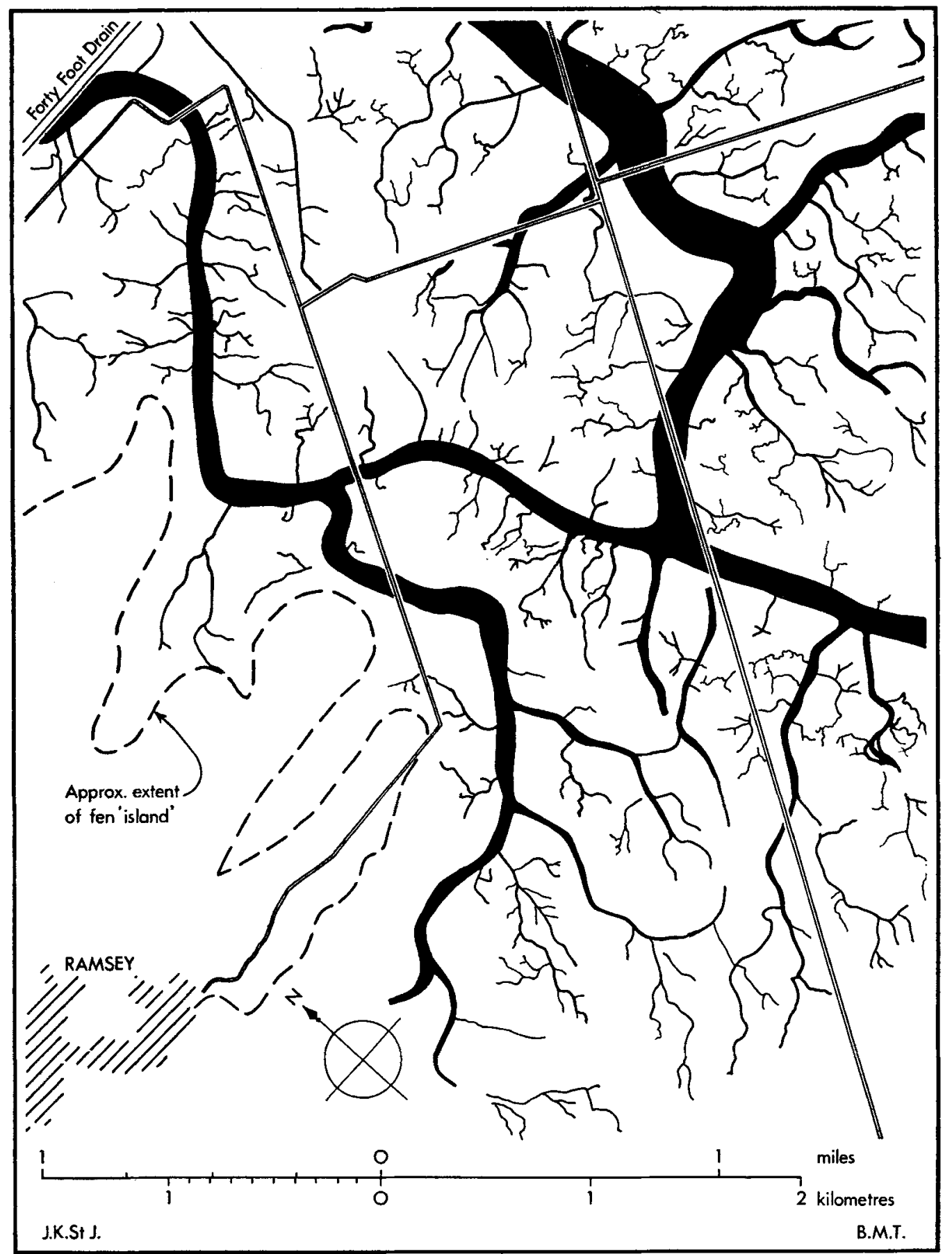

Fig. I. Map of the extinct river system in the Fenland $E$ of Ramsey, Huntingdonshire, drawn from air photographs; cf. PL. XXXVI 


\section{ANTIQUITY}

astonishingly complete picture of extinct rivers, not only the major channels but also the minor tributaries that reach to every part of the Fen. This conjures up a vivid picture of the conditions of the fens before the seventeenth century drainage.

An interesting comparison may be made between FIG. I and Hayward's map of I604, perhaps the earliest surviving survey of the Fens showing any degree of detail (Hayward, I604). The map shows the state of the Fens before the great drainage schemes, and readily enables many of the principal waterways to be identified on air photographs. The main river in the upper right-hand quadrant of FIG. I is a part of the natural course of the Ouse, the old 'West Water', to use the name adopted on Hayward's map and in Blaeu's survey (Blaeu, I645). This meanders through the Fens from Earith, northwards eventually to Wisbech. The pattern even of the main channels is far from simple as will be appreciated from FIG. I. Thus the arm that leads to the Forty Foot Drain seems to connect, as adjoining photographs show, with one of the outlets from Whittlesey Mere. Not all the channels may have been functioning at the same time: the rivers will have divided into distributaries, to unite again after the fashion of rivers crossing large areas of alluvium or of fenland.

Not only does the drawing suggest the remote nature of such marshland, impenetrable except by boat, but it also raises interesting questions about human settlement. The only Roman settlement recorded within the area of FIG. I is at Worlick at the $\mathrm{E}$ edge of the Ramsey 'island' (Phillips, 1970, sheet K: general distribution map). Yet the old channel of the Little Ouse from Littleport to Welney has Roman settlement sites clustered along it. A tongue of silt, indeed, extends south-eastwards past Welney beside the Little Ouse channel, but the roddon of the West Water, approximately $300 \mathrm{~m}$. broad towards the upper margin of FIG. I, is wide enough to have attracted settlement, if the levee were sufficiently high above the marshland to have made firm ground. Field-walking along the line of these old river channels may have much to reveal.

\section{J. K. ST JOSEPH}

BLAEU, J. 1645. Atlas major, sive cosmographia Blauiana, Vol. v (Amsterdam). (The plate of the fens, titled 'Regiones inundatae' is redrawn from a map by $\mathrm{H}$. Hondius dated 1632 .)

DARBY, H. C. 1950. The draining of the Fens (Cambridge).

FOWLER, G. I 934. The extinct waterways of the Fens, Geogr. F., Lxxxill, 30-9.

GoDWIN, H. I938. The origin of roddons. Geogr. $\mathcal{F}$, $\mathrm{XCI}, 241-50$.

hayward, w. I604. Plan of the Fenns. (This map is only known from 'an exact copy' by the surveyor Tayler Smyth, made in 1727 : this is now held in the Cambridgeshire County Record Office.)

PHILlips, c. w. (ed.). I970. The Fenland in Roman times, RGS Research Series, v.

\section{Probable trephination of five Early Saxon skulls}

PLATE XXXIV

This note describes and discusses four skulls from Norfolk and one from Suffolk, each of which has a well healed perforation.

\section{DESCRIPTION}

I. Swaffham, Inhumation ' $A$ '. (Wilson et al., 1970; 1971). The skull of a man aged $30-40$ years. It is rugged in build, of typical AngloSaxon type, it is a long ovoid in norma verticalis and has a Cranial Index of 69.3 (dolichocranial).

There is an elliptical groove in this skull, the long axis of which lies about $6 \mathrm{~mm}$. to the left of the mid-sagittal plane in the obelionic region of the L. parietal bone (PL. xxxiva). The floor of the groove is perforated and medially it trangresses the sagittal suture to encroach very slightly on the R. parietal. Its overall dimensions are: anteroposterior, $42.8 \mathrm{~mm}$.; transverse, 22.5 $\mathrm{mm}$. - these being the measurements across the top of the bevelled edge. The orifice is $16.4 \times$ $10.7 \mathrm{~mm}$. in diameter and its margin is cleanly healed except for a few millimetres where it shows some post-inhumation damage. The bevel around this orifice is smooth, well healed and slightly steeper at each side than at its anterior and posterior ends. The sides descend at an angle of about $50^{\circ}$, the ends at about $30^{\circ}$, from the plane of the surrounding bone. The process of repair has led to a low (c. I $\mathrm{mm}$.) heaping of the bone along that part of the margin of the groove 
